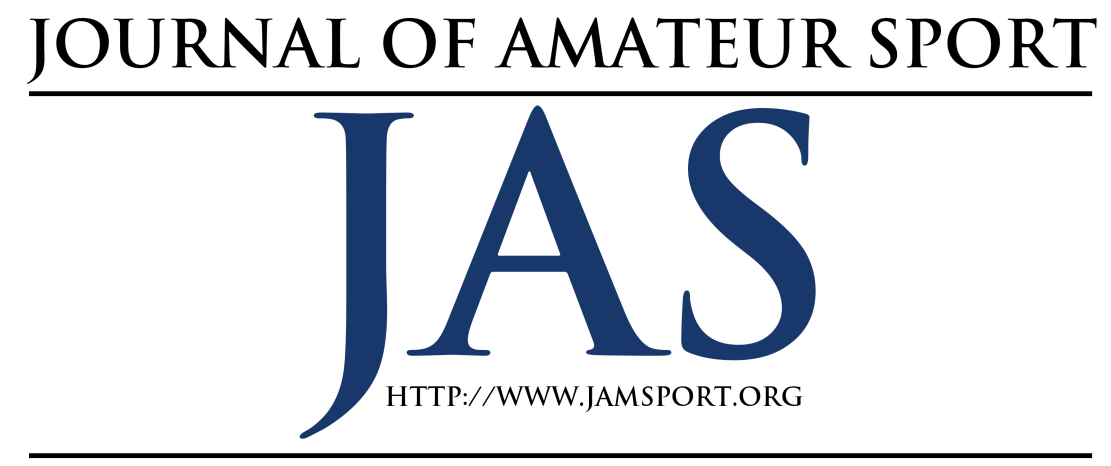

\title{
The Impact of Role Conflict on Job Satisfaction of Independent School Athletic Directors
}

\author{
Elizabeth Bradford Conant \\ Regis College
}

\begin{abstract}
Role conflict and job satisfaction were measured for 56 independent school athletic directors whose schools were members of the New England Preparatory School Athletic Council (NEPSAC). Simple linear regression analysis was used to test if role conflict significantly predicted the NEPSAC athletic directors' ratings of job satisfaction. Results of simple linear regression revealed that role conflict significantly predicted job satisfaction. Results of a one-way analysis of variance (ANOVA) revealed significant differences between the levels of programs served (middle school, high school-only, or combined middle and high school) for role conflict, but not for job satisfaction. It was also determined that no significant differences existed between athletic directors working at boarding schools versus day schools, or co-ed schools versus single-sex institutions, on either role conflict or job satisfaction.
\end{abstract}

thletic directors have seen their jobs
enlarge to encompass multiple
educational roles within and outside of school. Weight and Zullo (2015) described how, at the intercollegiate level, modern-day athletic directors have absorbed many of the responsibilities and challenges typically faced by chief executive officers, educators, and politicians. At interscholastic public high schools, athletic directors must respond to mandates from state and local governments and athletic governing bodies, in addition to leading their respective athletic programs. As public school systems responded to mandates such as No Child Left Behind (No Child Left Behind [NCLB], 2003) and more recently, the Every Student Succeeds Act (Every Student Succeeds [ESSA], 2015) for increasing academic rigor, funding for other school needs diminished (Patzkowski, 2008). This means that many athletic directors at public schools are also responsible for locating and maintaining alternative funding sources. 
At independent schools, athletic directors must contend with the pressures of managing the expectation levels of parents who have a vested financial interest in their child's experience (Mayes, 2007). Many of these schools offer extensive programming, state-of-the-art facilities, and top-notch educators, and as a result, their tuition rates can rival those of private colleges. Northeastern states have some of the priciest independent schools, and the highest tuition costs are at schools in Massachusetts and Manhattan (Zeveloff \& Galante, 2011).

The position of athletic director has many common roles and responsibilities, regardless of the institution or level. Schneider and Stier (2001) noted that it does not matter if one is an athletic director at a high school, a junior college, or a college/university - the elements of administering the sports program are essentially the same. The increased expectations and expanded roles for interscholastic athletic directors (Ha, Hums, \& Greenwell, 2011; Hoch, 2008; Kalahar, 2011; Nagel, 2012; Schnieder \& Stier, 2001; Sullivan, Lonsdale, \& Taylor, 2014) as well as intercollegiate athletic directors (Robinson, Peterson, Tedrick, \& Carpenter, 2003; Ryska, 2002; Weight \& Zullo, 2015) have been documented in the literature. However, there is a paucity of research on independent school athletic directors in general, and specifically, there exists a gap in the literature on the impact of the increased expectations and expanded roles of athletic directors at independent schools.

The lack of research on independent school athletic directors is surprising, considering the number of independent school athletic programs nationwide. The report "Independent School Facts at a Glance for: The National Association of Independent Schools (NAIS)" 2014-15 edition, included 1098 NAIS member schools in the United States, with a total enrollment of over 556,643 students (National Association of Independent Schools, 2015). Yet overall, the research focus has been almost exclusively on interscholastic athletic directors at public schools or intercollegiate athletic directors.

While there are commonalities between the positions of athletic director regardless of the school type, there are also differences between public schools and independent schools (Braun, Jenkins, \& Grigg, 2006). The defining distinction between public and independent schools is the different sources of support (National Center for Education Statistics, 1997). Public schools depend primarily on local, state, and federal government funds, while independent schools are usually supported by tuition payments and sometimes by funds from other nonpublic sources such as religious organizations, endowments, grants, and charitable donations. In the NAIS (2015) "Facts at a glance" materials, the average median tuition for an independent day school, grades $9-12$, was $\$ 24,402$. For 
boarding schools, grades 9-12, the average median tuition was $\$ 50,811$ (NAIS, 2015).

In marketing materials produced by the NAIS, there is an emphasis on "The strong sense of community beyond the classroom" (NAIS, 2004, p. 14) that serves as a distinction between independent schools and other K-12 institutions. These community-building activities include lunches and dinners proctored by faculty who sit at the head of every table, to frequent school assemblies, art shows, theater groups, school trips, and weekend sporting events that bring the whole school together (NAIS, 2004). At independent schools, athletic directors are expected to take part in all of these community activities, in addition to their role as the individual in charge of the athletic program.

College preparation is another potential area of distinction for athletic directors. In terms of college enrollment post high school, the percentage of public school students enrolling in college in the fall immediately following high school completion was 65.9 percent (National Center for Education Statistics, 2013). However, at independent schools, nearly 100 percent of students go onto college (Chubb, 2016). An independent school athletic director, therefore, might be faced with additional expectations and responsibilities regarding college counseling as well as athletic recruiting. Based on these distinctions and given that an examination of independent school athletic directors could yield similar or possibly very different results to previous studies of intercollegiate and interscholastic athletic directors, the need for further research on independent school athletic directors is compelling.

There is an understanding among independent school athletic directors that "wearing many hats" is an expectation and a reality (J. McNally, personal communication, December 6, 2015). On the NAIS website, the essential duties and responsibilities of the athletic director are detailed, along with other duties that may be required of the position. These other duties include coaching responsibilities, dorm duties, advising, evening and weekend duties, or public appearances on behalf of admissions (NAIS, 2016). With the possibility of multiple roles and expectations being assigned to an independent school athletic director, it is easy to imagine how they could become overwhelmed, or possibly less satisfied, in their positions. At some point, it is feasible that having too many roles, or more specifically too many competing roles and responsibilities, could take a negative toll on an athletic director.

A perspective on an employee having too many competing roles and responsibilities is role theory. Kahn, Wolfe, Quinn, Snoek, and Rosenthal (1964) proposed a model that suggested that organizational factors (the employee's environment) affect the expectations of individuals concerning role behavior. Role theory posits that when the behaviors expected of an individual by others in the organization are inconsistent, he or she will 
be in a state of role conflict and will experience stress, become dissatisfied, and perform less effectively than if the expectations did not conflict (Hamner \& Tosi, 1974). A key insight of this theory is that role conflict occurs when an individual is expected to simultaneously perform multiple roles that have conflicting expectations.

According to Kahn et al. (1964), role conflict is defined as "the simultaneous occurrence of two (or more) sets of pressures such that compliance with one would make more difficult compliance with the other" (p. 19). Moreover, role conflict tends to reduce an employee's general satisfaction with their job (Kahn et. al., 1964). While independent school athletic directors likely experience some role conflict, the impact of such role conflict on job satisfaction is not well understood. That is, it is unclear if job satisfaction levels vary depending on factors such as the type of roles, and/or the number of roles.

\section{Role of Athletic Director}

According to the annual High School Athletics Participation Survey (National Federation of High Schools, 2015), the number of participants in high school sports in 2014-2015 increased for the 26th consecutive year, totaling 7.8 million high school athletes. More athletes means more teams, more coaches, and more games. The additional athletes in athletic programs could mean additional responsibilities for athletic directors. For example, in their study of high school athletic directors from a Midwestern state, Sullivan, Lonsdale, and Taylor (2014) noted that in addition to growth in participation, there has been a corresponding expansion of responsibilities and expectations for the high school athletic director. The concept of expanding responsibilities was also examined by Eckman and Kelber (2010) who, in their study of high school principals, reported that as school size increases, so does the magnitude of instructional and management issues.

Nagel (2012) explained that the work for interscholastic athletic directors involves a variety of duties, including scheduling and supervising games and events, hiring and supervising coaches, scheduling transportation to away events and game officials for home events, maintaining facilities, and ordering equipment and uniforms. Nagel shared the example of an Ohio public school athletic director who calculated that in the first six months of the 2011-2012 academic year, he worked 155 out of 174 days, including 83 days that involved evening events where an athletic administrator must be present.

Fund-raising has become an additional responsibility that is increasingly requiring more time and energy from interscholastic athletic directors. As Patzkowsky (2008) noted, athletic directors are at the mercy of their school districts, which often struggle with maintaining levels of funding. Van Milligen (2013) observed that the pressure to generate more revenue on the high 
school level has continued to increase, forcing many athletic directors to get more involved in the fundraising process. McGrath (2015) asserted that raising money for high school athletics seems to get tougher every year. At many schools, athletic booster clubs exist to help athletic departments fill the funding gaps. While athletic directors are grateful to the time and money that the booster clubs members donate to the athletic department, attending meetings and assisting with logistical planning are additional responsibilities which occupy an athletic director's time.

In some cases, athletic directors are not just responsible for running the athletic department. At the interscholastic level, there has been a trend of combining the athletic director with other duties. In a 2005 National Interscholastic Athletic Administrators Association (NIAAA) national survey of interscholastic athletic directors, 45 percent of the athletic directors who responded to the survey reported that they were also responsible for tasks outside of a school's sports program (NIAAA, 2005). A smaller survey $(N=24)$ conducted by Kalahar (2011) of interscholastic athletic directors in Michigan revealed that 8 of the 24 athletic director positions were combined with the role of assistant principal. Five athletic directors reported they were responsible for teaching classes, and three athletic directors in the survey were also the school principal or co-principal.

Larson (2007) reflected on the past 50 years of independent school athletics and concluded that there has been an explosion of afternoon athletic offerings. Athletic programs have gone from having nine or ten sports in the past to programs that now have 30 or more different sport team options, plus activity class offerings. For example, at Miss Porter's School, an independent boarding and day school in Connecticut for girls in grades 9-12, there are 321 students, and the athletic department offers 18 different sports, totaling 32 teams over 3 levels (varsity, junior varsity, and thirds) and 12 fitness activity classes (Miss Porter's School, n.d.). Also located in Connecticut is KingswoodOxford School, which is an independent day middle and high school for boys and girls. There are 508 students total, and the athletic department offers 24 different sports, totaling 55 teams over four levels, including middle school (KingswoodOxford, n.d.).

As a frame of reference, the average NCAA Division III athletic program offers 18 sports and the average percentage of the student body participating in sports is 21 percent (National Collegiate Athletic Association, 2014). At independent schools, most if not all students are often required to participate in team sports, intramurals, or activities each of the three sport seasons. Independent schools typically offer a wide range of athletic opportunities for students and they encourage students to try a variety of sports (AISNE, 2016). 


\section{Role Conflict}

Role conflict was defined by Rizzo, House, and Lirtzman (1970) in terms of the dimensions of congruency-incongruency or compatibility-incompatibility in the requirements of a role, where congruency or compatibility is judged relative to a set of standards or conditions which impact role performance. When faced with role conflict, people have to make choices. Feeling forced to choose among competing roles is not a new problem, seeing that among the teacher-coaches interviewed in Sage's (1987) field research nearly thirty years ago, there was consistent agreement among the participants that they gave priority to their coaching and that as a result, their classroom preparation got shortchanged. In Paul's (1974) study of high school teachers, the author noted,

Role incumbents use a variety of adjustment mechanisms to accommodate conflict. When there is a choice among conflicting role pressures, the choice is most influenced by perception of legitimacy of instructions received and perceptions of sanction attached to the conflicting claims. (p. 241)

According to Brown, Jones, and Leigh (2005), when juggling too many demands, some employees may feel forced to stretch their attention, effort, and resources, which could impact even high performers' estimates of their self-efficacy, acceptance of challenging personal goals, and subsequent performance levels. For professionals working in the field of athletics, role conflict has been examined from many perspectives, including teachercoach (Figone, 1994; Richards \& Templin, 2012; Richards, Templin, Levesque-Bristol, \& Blankenship, 2014; Sage, 1987) physical education teacher-athletic directors (Ha et al., 2011), and certified athletic trainerclinical instructors (Henning \& Weidner, 2008). Schmidt, Roesler, Kusserow and Rau (2014) reported that role conflict leads to a psychological conflict in which employees will not be capable of fulfilling every expected role at the same time. Henning and Weidner (2008) reported that the athletic trainers in their study felt strained professionally as their role obligations increased to include clinical instruction, health care provision, and administrative responsibilities.

Role conflict can also occur when pressures from an individual's professional role are incompatible with the pressures from their personal roles. In Dixon and Bruening (2005), the researchers noted that in general, the sport industry is characterized by working long hours (including nights and weekends) in which face time is strongly valued. For the mothers in Bruening and Dixon's (2007) study of Division I women's basketball coaches, role conflict was a constant struggle. The coaching profession, especially at the Division I level, necessitates long hours, working nights and weekends, and traveling away from home. Such working conditions were in direct conflict with many 
parental roles and responsibilities, and often caused the mothers in the study great emotional strain. More recently, research on the work-family interface has expanded to include the experiences of coaching fathers, who like their counterparts in other professions, perceive tension between work and family (Graham \& Dixon, 2014).

According to Kahn et al. (1964), the presence of role conflict tends to reduce an employee's general satisfaction with their job. For the principals in Eckman and Kelber's (2010) study, there was a statistical correlation of role conflict with job satisfaction for the group. The authors stated "As role conflict increased for these principals $(N=102)$, job satisfaction decreased" (p. 214). In a study of job satisfaction in intercollegiate Division III athletic directors, the presence of role conflict could be inferred in a comparison of intercollegiate athletic directors. Specifically, the job satisfaction levels of those athletic directors with multiple functions and job responsibilities were compared to those of Division III athletic directors who devoted all their time to athletic director duties. Notably, the study raised concerns that Division III athletic directors with multiple roles and responsibilities were more prone to job dissatisfaction than those Division III athletic directors who devoted all their time to athletic director duties (Robinson et al., 2003).

\section{Job Satisfaction}

Job satisfaction has been defined as the perceived equity between expected and actual job rewards (Ivancevich \& Donnelly, 1974), the affective reactions that an employee has to a job (Fields, 2002), the way that employees feel about their jobs (McChesney \& Peterson, 2005), as well as a positive emotional response resulting from an employee's job expectations being met or exceeded (Mathis \& Jackson, 1991). Issues surrounding job satisfaction exist in every profession, noted Terranova and Henning (2011), and the nature of the profession might influence the degree of satisfaction.

After reviewing previous studies involving the topic of job satisfaction in the workplace, it can be inferred that job satisfaction can be influenced by a variety of factors, including role ambiguity (Blalack \& Davis, 1975; Paul, 1974), role conflict (Eckman \& Kelber, 2010), role conflict and ambiguity (Cervoni \& DeLucia-Waack, 2011; Dhurup \& Mahomed, 2011; Hamner \& Tosi, 1974; Schmidt et al., 2014), and role stress (Bacharach, Bamberger, \& Conley, 1991; Faucett, Corwyn, \& Poling, 2013). Job satisfaction has also been studied from the perspective of contributing to the overall function of work organizations. According to Spector (1997), this is important at least partly because it appears to contribute to positive job attitudes and work behaviors such as job involvement and organizational commitment. In the field of higher education, increased job satisfaction and better retention of faculty 
reduces the need for costly faculty selection and hiring. Additionally, higher retention adds financial stability in the institution (Froesche \& Sinkford, 2009). Faculty job satisfaction and its relationship to retention in higher education are business related issues, as a $5 \%$ increase in retention can lead to a $10 \%$ reduction in costs (Wong \& Heng, 2009).

Terranova and Henning (2011) studied the job satisfaction of intercollegiate athletic trainers and found that athletic trainers who reported less job satisfaction also reported greater intention to leave their jobs.

McChesney and Peterson (2005) noted that a lack of satisfying job attributes can lead to gradual burnout in an employee, or gradual distress, which can lead to absenteeism and turnover. According to Smith (1992), job dissatisfaction because of high workload, lack of control, and lack of recognition and reward can affect marital, family, and leisure satisfaction.

In their study of job satisfaction among faculty members, Foor and Cano (2011) stressed that individuals such as department chairs, directors, deans and others involved in administration and supervision should be concerned with the job satisfaction of their employees. The supervisors of NCAA Division III athletic directors, noted Robinson et al. (2003), have a vested interest in improving job satisfaction in the hope of reducing organizational attitudes and adaptive responses that would be viewed as detrimental to the organization. More specifically, the researchers noted that organizational leaders need to be cognizant to the elements of a Division III athletic director's job that promote job satisfaction or dissatisfaction (Robinson et al., 2003).

The focus of the current study is the impact of role conflict on job satisfaction. This topic has been the focus of studies in a variety of professions, including high school counselors (Cervoni \& DeLucia-Waack, 2011), high school principals (Eckman \& Kelber, 2010), teachers (Paul, 1974), nurses and engineers (Bacharach et al., 1991), and United Methodist clergy (Faucett et al., 2013). In the athletic realm, Ryan and Sagas (2006) studied the impact of inter-role conflict on the job satisfaction and intent to leave of interscholastic teacher-coaches and found that the conflict experienced between the roles of teacher and coach can be detrimental to satisfaction.

For the purposes of this study, however, the researcher uncovered far fewer studies specifically focusing on the impact of role conflict on job satisfaction of independent school athletic directors. One such study was conducted of public school sport facilitators in South Africa. Dhurup and Mahomed (2011) reported that for the educators in their study $(N=128)$, role conflict had a significant negative impact on job satisfaction. Specifically, when the educators took on multiple roles (in this case, teacher and sport facilitator), the result was increased levels of inter-role conflict.

Less is known about the impact of role conflict on job satisfaction of independent school athletic directors. In particular, New 
England Prep School Athletic Council (NEPSAC) athletic directors are a population that until this point has not been the focus of research studies in the field of Sport Management. For the purposes of this study, the researcher sought to examine the impact of role conflict on the job satisfaction of athletic directors at NEPSAC member schools. Within the present study the researcher included factors such as residence type (boarding or day school), school type (co-educational or single sex), or program level (high school only, high school and middle school combined, middle school only) in an attempt to examine what, if any, impact these factors have on levels of role conflict and job satisfaction of independent school athletic directors.

\section{Hypotheses}

The expanding roles of interscholastic athletic directors and intercollegiate athletic directors have been the focus of numerous studies. However, little is known about the impact of role conflict on job satisfaction for independent school athletic directors. The position of athletic director has many common roles and responsibilities regardless of the institution or level (Schneider \& Stier, 2001), yet the independent school athletic director may also be expected to fulfill additional and/or conflicting roles not expected in public schools or colleges. For example, an athletic director at an independent boarding school might also be expected to live in the dormitory or have dorm duty responsibilities. An athletic director at an independent day school might be responsible for chaperoning or driving to weekend activities, in addition to coaching or supervising weekend athletic events (Powell, 1996). An independent school athletic director, especially at the high school level, could have increased college counseling and athletic recruiting pressures (Chubb, 2016). Working as an athletic director at a co-educational institution could mean offering twice as many teams, having twice as many athletes, and having twice as many coaches to supervise as opposed to serving as an athletic director at a single-sex institution. Taking these additional and/or conflicting roles into consideration, it is possible that role conflict may impact the job satisfaction of independent school athletic directors.

Hypothesis 1: NEPSAC athletic directors with high levels of role conflict will display significantly lower levels of job satisfaction.

Hypothesis 2a: NEPSAC athletic directors at boarding schools will experience more role conflict than athletic directors at NEPSAC day schools.

Hypothesis 2b: NEPSAC athletic directors at boarding schools will report less job satisfaction than athletic directors at NEPSAC day schools. Hypothesis 3a: NEPSAC athletic directors at co-educational schools will experience more role conflict than athletic directors at single-sex schools. 
Hypothesis 3b: NEPSAC athletic directors at co-educational schools will report less job satisfaction than athletic directors at single-sex schools.

Hypothesis 4a: NEPSAC athletic directors in charge of high school athletic programs, or combined high school and middle school programs, will experience more role conflict than athletic directors at middle schools. Hypothesis 4b: NEPSAC athletic directors in charge of high school athletic programs, or combined high school and middle school programs, will report less job satisfaction than athletic directors at middle schools.

\section{Method}

\section{Participants}

Independent school athletic directors from the New England Preparatory School Athletic Council (NEPSAC) were selected. NEPSAC was established in 1942 as an organization of athletic directors from accredited New England independent schools. While the association does not function as a regulatory or oversight body (like the NCAA or state public high school associations), NEPSAC does sanction New England championship events in many sports and provides guidance in a variety of issues involving interscholastic athletics (New England Preparatory School Athletic Council, n.d.). The NEPSAC member schools represent all six New England states plus eastern New York State, and include three residence types: day schools, boarding schools and combined day and boarding schools. In addition, all NEPSAC schools are one of two education types: coeducational or single-sex education. Schools in the NEPSAC serve middle school grade levels, high school grade levels, or a combination of both middle and high school grade levels.

A total of 172 independent school athletic directors were sent the online survey measuring role conflict and job satisfaction. The email addresses of athletic directors from all member schools were provided by NEPSAC for the purpose of data collection. One follow-up email was sent 10 days after the initial distribution to promote survey participation. The first wave of collection resulted in 34 responses, and the second, follow-up wave elicited an additional 22 responses to the survey. According to Jordan, Walker, Kent, and Inoue (2011), it is important for researchers to consider the threat of nonresponse error. One method of defining groups is to classify respondents based on successive waves of responses to a questionnaire (Dooley \& Lindner, 2003). This would mean that all participants who responded after a follow-up notice has been sent would be grouped in the last wave and thus be deemed "late respondents" (Jordan et al., 2011). Dooley and Lindner (2003) reported that late respondents have been shown to be an appropriate proxy for nonrespondents. In Paul's (1975) study of high school teachers, the researcher conducted telephone interviews with non- 
respondents to be sure that non-response error would be avoided.

In the current study, the researcher identified two waves of collections, wave one and wave two. Results of an independent samples $t$-test did not reveal significant differences between wave one respondents and wave two respondents for role conflict $(t(52)=.008, p=.528)$. The reported levels of role conflict for athletic directors in wave one $(M=2.91, S D=.877)$ were nearly identical to the reported levels of role conflict for athletic directors in wave two $(M=2.91, S D=.804)$. Similarly, results of an independent samples $t$-test did not reveal significant differences in reported job satisfaction levels between wave one respondents and wave two respondents $(t$ $(52)=-.159, p=.057)$ as athletic directors in wave one $(M=4.07, S D=.773)$ were comparable to athletic directors in wave two $(M=4.10, S D=.515)$.

There were a total of 56 completed questionnaires for a $32.5 \%$ survey response rate. Among all respondents, 52 completed the instrument in its entirety. The respondents included 44 males $(78.6 \%)$ and 12 females $(21.4 \%)$. The ages of the athletic directors ranged from 29 to $76(M=48.9$, $S D=9.1)$. There was a wide range in the length of an athletic director's tenure at his or her current school $(M=9.8$ years, $S D=$ 8.7) with six athletic directors in the first year at his or her current institution and one athletic director serving in the thirty-eighth year as the athletic director at the current school. The average amount of total experience as an athletic director at any independent school was slightly higher ( $M=$ 12.6 years, $S D=10.5)$.

In terms of institutional characteristics, the majority of participants $(48.2 \%)$ reported that they were employed as athletic directors at day schools, $30.4 \%$ were at combined boarding and day schools, and $21.4 \%$ worked at boarding schools. The vast majority $(78.6 \%)$ of those surveyed were coeducational school athletic directors, while $21.4 \%$ were athletic directors at single-sex institutions. The majority of athletic directors were in charge of competitive programs that served both middle and high school students (44.6\%) and high schoolonly $(39.3 \%)$, while $16.1 \%$ oversaw middle school-only athletic programs.

The NEPSAC athletic directors reported a wide variety of additional responsibilities, including coaching, dorm duty, and teaching. When the athletic directors were asked how many seasons they were currently coaching a team, $44.6 \%$ coached one season, $26.8 \%$ coached two seasons, and $8.9 \%$ coached all three seasons; meanwhile, $19.6 \%$ reported that they were not currently coaching a team. For athletic directors employed at boarding schools or combined boarding and day schools, some amount of dorm duty was a frequent requirement. Twenty-eight respondents indicated that they have dorm duty responsibilities, the majority of which (25\%) had dorm duty one night a week. At many NEPSAC schools, the athletic directors were expected to teach classes. While 
twenty-one $(37.5 \%)$ of the athletic directors surveyed stated that they had "zero" teaching responsibilities, the majority $(62.5 \%)$ reported that they were responsible for teaching at least one class each semester.

When given the opportunity to provide details regarding any other roles that were included in their job responsibilities, thirtyone $(55 \%)$ of the NEPSAC athletic directors provided examples. Additional oncampus roles that were filled by those athletic directors included: faculty advisor to students (15\%), Director of Physical Education (13\%), Administrator on Duty $(13 \%)$, and Admissions Committee (9\%). Additionally, three athletic directors reported being in charge of transportation at their school, two individuals worked in their schools' College Counseling office, one did technology work for their school, and one athletic director also served as the dean of the middle school.

\section{Survey Instrument}

The research was conducted using a survey format and contained demographic questions as well as Likert scale type questions (see Appendix A). Role conflict was examined using items taken from the Role Questionnaire developed by Rizzo et al. (1970), which was one of the first measures of role conflict (Field, 2002). The eight role conflict items were reliable ( $\alpha=$ $.88, M=20.37, S D=3.21$ ). The responses to the Role Questionnaire (Rizzo et al., 1970) were obtained using a seven-point Likerttype scale where $1=$ very false and $7=$ very true. Examples of role conflict items on the questionnaire included "I have to do things that should be done differently" and "I receive assignments without adequate resources and material to execute them (Rizzo et al., 1970, p. 56).

Job satisfaction was measured using the Job Satisfaction Relative to Expectations survey, developed by Bacharach et al. (1991). This measure assessed the degree of agreement between the perceived quality of broad aspects of a job and employee expectations (Fields, 2002). According to Fields, this measure is particularly useful to assess the extent to which job stresses, roles conflicts, or role ambiguity prevent job expectations from being met.

The choice of this particular scale for the present study, with the emphasis on job satisfaction relative to expectations, made sense as athletic directors are responsible for multiple roles, and at times, fulfilling the expectations of one of those roles may conflict with fulfilling the expectations of another role. Bacharach et al. (1991) determined that the scale correlated negatively with role conflict, role overload, and work-home conflict. The reported negative correlation aligned with the current researcher's hypothesis that NEPSAC athletic directors with high levels of role conflict will display significantly lower levels of job satisfaction. Cronbach's alpha for the five items on this survey was reliable ( $\alpha=$ .83, $M=23.35, S D=6.55)$. The responses to the Job Satisfaction Relative to Expectations survey (Bacharach et al., 1991) were 
obtained using a four point Likert-type scale where $1=$ very dissatisfied and $4=$ very satisfied. Examples of items on the measure included "Your present job when you compare it to others in the organization" and "Your present job in light of your career expectations" (Bacharach et al., 1991, p. 45).

\section{Results}

Simple linear regression analysis was used to test hypothesis 1 : NEPSAC athletic directors with high levels of role conflict will display significantly lower levels of job satisfaction. Role conflict significantly predicted the NEPSAC athletic directors' ratings of job satisfaction. Specifically, results of a simple linear regression revealed that job satisfaction $\left(F(1,51)=29.418, R^{2}=\right.$ $.38, p=.000)$ was significantly predicted by role conflict $(\beta=-.616, t=-5.424, p=$ $.000)$.

The results of an independent samples $t$-test did not reveal significant differences when testing hypothesis $2 \mathrm{a}$, whether NEPSAC athletic directors at boarding schools will experience more role conflict than athletic director's at NEPSAC day schools $(t(52)=-.434, p=.460)$. A closer examination of the means suggested that athletic directors at boarding schools $(M=$ 2.964, $S D=.789$ ) did not report experiencing more role conflict than athletic directors at day schools $(M=2.864, S D=$ .867). When testing hypothesis $2 \mathrm{~b}$, whether NEPSAC athletic directors at boarding schools will report less job satisfaction than athletic directors at NEPSAC day schools, the results of an independent samples $t$-test did not reveal significant differences between residence type for job satisfaction $(t(52)=.074, p=.135)$. For athletic directors at boarding schools $(M=4.06, S D$ $=.141$ ), levels of job satisfaction were nearly identical to athletic directors at day schools $(M=4.08, S D=.535)$.

Results of an independent samples $t$-test did not reveal significant differences between education type for role conflict $(t$ (52) $=-1.535, p=.817$ ), when testing Hypothesis 3a, whether NEPSAC athletic directors at co-educational schools will experience more role conflict than athletic directors at single-sex schools. Athletic directors at co-educational schools $(M=$ 3.012, $S D=.785$ ) reported slightly more role conflict than athletic directors at singlesex schools $(M=2.604, S D=.887)$, but the results did not achieve significance. The results of an independent samples $t$-test did not indicate significant differences between education types for job satisfaction $(t(52)=$ $1.629, p=.524)$ when testing hypothesis $3 \mathrm{~b}$, if NEPSAC athletic directors at coeducational schools will report less job satisfaction than athletic directors at singlesex schools. An examination of the means suggested that athletic directors at coeducational institutions $(M=3.99, S D=$ .620) had slightly lower levels of job satisfaction than athletic directors at singlesex schools $(M=4.33, S D=.667)$, but not significantly. 
Results of a one-way ANOVA were used to test hypothesis $4 \mathrm{a}$, if NEPSAC athletic directors in charge of high school athletic programs, or combined high school and middle school programs, will experience more role conflict than athletic directors at middle schools. The results revealed significant differences between programs served for role conflict $(F(2,50)=4.722$, $p$ $=.013)$. A post hoc Bonferroni test found that athletic directors at middle schools $(M$ $=2.22, S D=.941)$ scored lower on the role conflict items than athletic directors who were in charge of both middle and high school athletic programs $(M=2.988, S D=$ $.809)$, and athletic directors in charge of high school athletic programs $(M=3.14$, $S D=.626$ ).

However, when testing hypothesis $4 \mathrm{~b}$, whether NEPSAC athletic directors in charge of high school athletic programs, or combined high school and middle school programs, will report less job satisfaction than athletic directors at middle schools, the results of a one-way ANOVA did not reveal significant differences between programs served for job satisfaction $(F(2,50)=1.58$, $p=.217)$. Athletic directors at middle schools $(M=4.33, S D=.458)$ reported similar levels of job satisfaction to those athletic directors who were in charge of both middle and high school programs ( $M$ $=4.13, S D=.577)$, and athletic directors at high schools $(M=3.904, S D=.742)$.

\section{Discussion}

The job satisfaction of athletic directors is becoming increasingly important as their jobs and the corresponding roles that they are expected to perform continue to change and expand. Role theory posits that when the behaviors expected of an individual by others in the organization are inconsistent, he or she will be in a state of role conflict and will experience stress, become dissatisfied, and perform less effectively than if the expectations did not conflict (Hamner \& Tosi, 1974). For the purposes of this study, the researcher examined the potential impact of role conflict on job satisfaction. Given the possible outcomes of lower job satisfaction ratings, including intention to leave a job, Foor and Cano (2011) urged supervisors to be concerned with the job satisfaction of their employees. Researchers have studied job satisfaction as it relates to athletic trainers (McChesney \& Peterson, 2005, Terranova \& Henning, 2011) as well as intercollegiate athletic directors (Robinson et al., 2003).

However, no study to date has specifically examined the impact of role conflict on job satisfaction of independent school athletic directors. Thus, the purpose of this study was to investigate job satisfaction levels of current NEPSAC athletic directors. Specifically, the researcher used the role conflict items from the Role Questionnaire (Rizzo et al., 1970) and the Job Satisfaction Relative to Expectations survey (Bacharach et al., 1991) in an attempt to predict whether NEPSAC athletic 
directors who reported more role conflict would have less job satisfaction. Additional research questions sought out differences in these areas between the groupings of residence type, education type, and level of programs served.

In terms of the overall levels of role conflict, NEPSAC athletic directors appear to be dealing with some amount of role conflict in their jobs. The majority of the athletic director's reported coaching at least one season, more than half of the sample had dorm duty responsibilities, and nearly two-thirds of the respondents taught at least one class. Thus, most of the NEPSAC athletic directors were managing at least four different roles on campus. But it is not simply the number of roles that causes an individual to experience role conflict. Kahn et al.. (1964) explained that role conflict is the simultaneous occurrence of two (or more) sets of pressures such that compliance with one would impact compliance with the other. If an athletic director was involved in their administrative role (meeting with coaches on their staff, calling opponents to schedule games), it is reasonable to suggest that they could not simultaneously fulfill their coaching, teaching or dorm duty roles.

Regarding the items on the job satisfaction survey, NEPSAC athletic directors reported high levels of job satisfaction overall. This is similar to Robinson et al.'s (2003) research on NCAA Division III athletic directors, who expressed a high level of satisfaction with their positions. In the Robinson et al. study, when respondents were asked to qualitatively respond to the question "What do you like most about your current position?" the most common response was working with and having an impact on student-athletes. In addition, respondents indicated that they enjoyed a high level of control and autonomy, and a high level of decision-making latitude. It is possible that the high job satisfaction ratings of the NEPSAC athletic directors in the present study are a reflection that they also enjoy working with and having an impact on the student-athletes, and they enjoy similar aspects of control, autonomy and decisionmaking power. But further research is needed to help identify the basis for the high levels of job satisfaction reported by the NEPSAC athletic directors.

However, when the results for the entire survey were tested by simple linear regression analysis, job satisfaction was negatively predicted by role conflict. This confirmed the researcher's hypothesis that NEPSAC athletic directors with high levels of role conflict will display significantly lower levels of job satisfaction. As noted by Kahn et al. (1964), when a person is confronted with two or more conflicting or opposing role expectations and the corresponding role demands of others, role conflict can occur. This leads to a psychological conflict in which the employee will not be capable of fulfilling every expected role at the same time. For an athletic director, their additional roles (e.g., 
coaching, teaching, dorm duty) might conflict with the role of athletic director, but in addition, these conflicts have an impact on other people. For example, if an athletic director is in an administrative meeting, they cannot meet with player on their team, or a student needing extra help, or a resident with a dorm issue. Therefore, it is possible that for some NEPSAC athletic directors, they feel as though they are shortchanging someone who needs them or expects something from them. As they struggle with managing role expectations and balancing conflicting responsibilities, their job satisfaction may suffer.

Results of the one-way ANOVA revealed significant differences between programs served for role conflict. Athletic directors at middle schools scored lower on the role conflict items than athletic directors who were in charge of both middle and high school athletic programs and athletic directors in charge of high school-only athletic programs. This confirmed the researcher's hypothesis that NEPSAC athletic directors in charge of high school athletic programs, or combined high school and middle school programs, will experience more role conflict than athletic directors at middle schools.

While the researcher is not suggesting that middle school athletic directors have "less on their plate" than an athletic director in charge of a high school athletic program, it is possible that middle school athletic directors have fewer conflicts within and between their different roles. According to
Chubb (2016), NAIS-member schools send the vast majority of students (nearly 100 percent) to college, with disproportionate numbers of them attending the most selective colleges and universities. College athletic recruiting is beginning earlier, often in ninth or tenth grade (Healy, 2015) and in elite cases, athletes are verbally committing by the end of their freshmen year. Athletes miss varsity practices and games for college visits in their junior and senior year. Students must take required exams, including SAT's, ACT's and Advanced Placement courses, and the scheduling of team practices and games must be planned accordingly. Since middle school athletes are not involved in the college process, managing issues pertaining to college recruiting is not one of a middle school athletic directors expected roles, which is one possible explanation for their lower reported levels of role conflict.

However, results of a one-way ANOVA did not reveal significant differences between programs served for job satisfaction. Athletic directors at middle schools reported similar levels of job satisfaction to those athletic directors who were in charge of both middle and high school programs and athletic directors at high schools. Considering that the average number of years that NEPSAC athletic directors had worked in their current role was 9.8 years, this potentially indicates that they are satisfied enough to remain in their position for an extended period of time, regardless of the program level served. 
The results of the independent samples $t$-test did not indicate significant differences between the groups, when testing whether differences in role conflict or job satisfaction existed between NEPSAC athletic directors at boarding schools and athletic directors at NEPSAC day schools. The researcher hypothesized that athletic directors at boarding schools would have more role conflict than athletic directors at day schools. Boarding schools require additional roles such as dorm duty, sit-down dinner, and chaperoning weekend activities, so additional role conflict was expected. In addition, faculty and staff at boarding schools are acting in loco parentis 24 hours a day, which is a huge responsibility. However, no significant differences emerged between residence types. The possible explanation for this is that although these are additional roles, they were not necessarily conflicting roles. Everyone has to eat, for example, so sit-down dinner responsibilities at a boarding school would not conflict with coaching or teaching. In addition, while the researcher was anticipating that athletic directors at boarding schools might less satisfied by living and working in the same environment, perhaps this arrangement has positive aspects, too; no commute, no rent/mortgage payments, ability to save money, and a sense of increased connection and community.

No significant differences emerged from the results of the independent samples $t$-test between co-educational and single-sex schools, either for role conflict or job satisfaction. Co-educational schools provide athletic opportunities for both genders as opposed to just one, so the researcher hypothesized that a co-ed athletic department would offer twice as many teams, have twice as many athletes, and have twice as many coaches to supervise as opposed to a single-sex institution. This would initially appear to be quite daunting, but in many cases, an athletic director has a support staff, such as associate and assistant athletic directors. Although the researcher did not control for the number of support staff positions in the present survey, it is feasible that athletic departments at larger schools with larger athletic programs would have a correspondingly larger staff. Although the volume of work might be greater in a co-educational athletic program, the number of conflicting roles for an athletic director at a co-educational school might not be very different from an athletic director at a single-sex school.

\section{Limitations}

In retrospect, it would have been helpful to broaden the scope of the survey and include more questions pertaining to different aspects of an athletic directors experience working at an independent school. The omission of control variables could impact the validity and generalizability of the findings. For instance, the researcher did not control for the number of full-time or part-time support staff in the athletic department. Did they have a full-time 
administrative assistant? Did their department also have assistant athletic director(s) and/or associate athletic director(s)? Having more staff would allow the athletic director to delegate certain roles or responsibilities, such as equipment inventory or attendance, to an assistant. Being able to delegate could then free the athletic director to focus on more important, and perhaps more satisfying, roles or responsibilities. In contrast, at some schools, an athletic director may have been the only full-time time staff member, which meant they were essentially doing everything on their own without support. This could contribute to increased role conflict, and in turn, possibly decreased job satisfaction.

Although the researcher in the present study did include questions on the survey regarding additional roles, such as whether an athletic director was also expected to coach a team and if they taught classes, asking for more details about those roles would have been useful. For example, there are different responsibilities and roles involved in being a head coach of a varsity team, as opposed to the head coach of a junior varsity team, thirds team or middle school team. Similarly, being a head coach at any level is different from being an assistant coach. In addition, there is a broad range in the responsibilities and roles involved in teaching a class. Is the class an advanced placement course, or a physical education skills class? Does the class meet five days a week or twice a week? How many courses are they teaching each semester, and how many course preps do they have?

The timing of when the survey was emailed to the NEPSAC athletic directors turned out to be a limitation. The initial email requesting participation in the survey, as well as the follow-up reminder email, coincided with the NEPSAC schools' two or three-week long spring break. Many athletic directors were away from their office, traveling with teams or on vacation. Therefore, it is possible that the timing limited the overall response rate, and it may have also limited the type of athletic directors who might have replied.

A final limitation is the concern of nonresponse bias. As Jordan et al. (2011) cautioned their readers, the issue of nonresponse bias can limit the external validity of a research study. The current study did separate the respondents into wave one and wave two, and no significant differences emerged. However, as Jordan et al. noted, the likelihood of nonresponse error in a study decreases as the response rate increases (presuming that adequate sampling procedures are employed), but it cannot be completely eliminated as a potential bias until some mechanism of control is instituted.

\section{Future Research}

There are many different directions for possible future research. It would be interesting to broaden the current survey, both in terms of the survey design as well as the sample population. Future survey design 
could include questions on numbers of support staff in the athletic department, the level of competition of the team(s) they were coaching, and the number and level of courses they were teaching. The researcher could broaden the survey population to a nationwide sample by sending the survey to all athletic directors at NAIS member institutions. Does role conflict impact the job satisfaction of athletic directors at independent schools outside of the NEPSAC? Is there a difference in the job satisfaction of independent school athletic directors in different regions of the country? Considering that the NAIS has over 1000 member schools nationwide, there is the potential to have a much larger sample to draw from.

Future research could also seek out more detailed information about the schools where the athletic directors work. Beyond the variables of residence type, education type and programs served, which were included in the present study, it would be interesting to examine the cost of school tuition for day and boarding students, total school enrollment, number of athletic participants, athletic requirements, how many sports and teams offered, and the number of coaches that the athletic director supervises. It would be useful to include qualitative, open-ended questions on a future survey to get more in-depth responses from the athletic directors in order to research possible reasons why certain athletic directors experience more role conflict and less job satisfaction.
Having such information would provide more context and means of comparison among the respondents and would allow for more in-depth analysis among the different variables.

From a gender perspective, it would be interesting to have a larger sample to determine if women actually hold less than a quarter of all athletic director positions at independent schools nationwide, or if it is a phenomenon exclusive to schools in the northeast. Comparing what differences, if any, exist between male and female athletic directors at independent schools could reveal if gender differences impact role conflict or job satisfaction. Finally, people have many roles in their lives, and not all of them are work-related. Therefore, it would be interesting to include demographic questions about marital status or the number of children living at home, and test for differences among men and women, married and single people, parents or not parents on the variables of role conflict and job satisfaction.

Finally, role theory includes additional variables beyond role conflict, and there are additional outcomes, beyond job satisfaction. As Hamner and Tosi (1974) explained, when the behaviors expected of an individual by others in the organization are inconsistent, he or she will be in a state of role conflict and will experience stress, become dissatisfied, and perform less effectively than if the expectations did not conflict. Future research could incorporate additional role theory variables and focus on 
the possible implications for independent school athletic directors, including the coping mechanisms of those who report higher levels of job satisfaction.

\section{Conclusion}

For the NEPSAC athletic directors in the present study, an inverse relationship existed between role conflict and job satisfaction. That is, when the athletic directors reported higher levels of role conflict, their job satisfaction decreased. This should be a concern for their heads of school, supervisors and hiring managers, considering the potentially negative outcomes of decreased job satisfaction, such as stress, burnout and intention to leave. However, when reviewing the results of the job satisfaction items on the survey, NEPSAC athletic directors reported high levels of job satisfaction overall. This is encouraging because when examined apart from role conflict, athletic directors still report feeling satisfied or very satisfied with their position. But, athletic directors are expected to perform multiple roles, and at times, those roles conflict. Hopefully, as more research is done on the subject, awareness will increase and efforts will be made to support NEPSAC athletic directors and perhaps limit their conflicting roles. 


\section{References}

Association of Independent Schools in New England (2016). Membership.

Retrieved from:

http://www.aisne.org/advancedsearch.html

Bacharach, S., Bamberger, P., \& Conley, S. (1991). Work-home conflict among nurses and engineers: Mediating the impact of role stress on burnout and satisfaction with work. Journal of Organizational Behavior, 12, 39-55.

Blalack, R. O., \& Davis, H. J. (1975). Role ambiguity, job-related tension and job satisfaction. Journal of Management, 1(1), 31-37.

Braun, H., Jenkins, F., and Grigg, W. (2006). Comparing Private Schools and Public Schools Using Hierarchical Linear Modeling (NCES 2006-461). U.S. Department of Education, National Center for Education Statistics, Institute of Education Sciences. Washington, DC: U.S. Government Printing Office.

Brown, S. P., Jones, E., \& Leigh, T. W. (2005). The attenuating effect of role overload on relationships linking selfefficacy and goal level to work performance. Journal of Applied Psychology, 90(5), 972-979. DOI 10.1037/0021-9010.90.5.972

Bruening, J., \& Dixon, M. (2007). Workfamily conflict in coaching II: Managing role conflict. Journal of Sport Management, 21(4), 471-496.
Cervoni, A., \& DeLucia-Waack, J. (2011). Role conflict and ambiguity as predictors of job satisfaction in high school counselors. Journal of School Counseling, 9(1).

Chubb, J. (2016). College prep? NAIS Magazine. Retrieved from: http://www.nais.org/MagazinesNewsletters/ISMagazine/Pages/Coll ege-Prep.aspx

Dhurup, M., \& Mahomed, F. E. (2011). Role ambiguity, role conflict and work overload and their influence on job satisfaction of sports facilitators in public schools in the Vaal Triangle, South Africa. African Journal for Physical, Health Education, Recreation and Dance (AJPHERD), 172-188.

Dixon, M. A. \& Bruening, J. E. (2007). Work-family conflict in coaching: A top-down perspective. Journal of Sport Management, 21, 377-406. DOI 10.1016/S1441-3523(05)70040-1

Dooley, L. M., \& Lindner, J. R. (2003). The handling of nonresponse error. Human Resource Development Quarterly, 14, 99-110. DOI 10.1002/hrdq.1052

Eckman, E. E. \& Kelber, S. K. (2010). Female traditional principals and coprincipals: Experiences of role conflict and job satisfaction. Journal of Educational Change, 11(3), 205-219. DOI 10.1007/s10833-009-9116-z

Every Student Succeeds Act (2015).

Retrieved from http://www.help.senate.gov/imo/m 
edia/doc/ESSA\%20FINAL\%20Con ference $\% 20$ Report

Faucett, J. M., Corwyn, R. F., \& Poling, T. H. (2013). Clergy role stress: Interactive effects of role ambiguity and role conflict on intrinsic job satisfaction. Pastoral Psychology, 62, 291-304. DOI 10.1007/s11089-0120490-8

Fields, D. L. (2002). Taking the measure of work: A guide to validated scales for organizational research and diagnosis.

Thousand Oaks, CA: Sage Publications.

Figone, A.J. (1994). Teacher-role conflict: Its impact on students and studentathletes. Physical Educator, 51(1).

Foor, R. M., \& Cano, J. (2011). Predictors of job satisfaction among selected agriculture faculty. Journal of Agricultural Education, 52(1), 30-39. DOI: $10.5032 /$ jae2011.01030

Froeschle, M. L., \& Sinkford, J. C. (2009). Full-time dental faculty perceptions of satisfaction with the academic work environment. Journal of Dental Education, 73, 1153-1170.

Graham, J. A., \& Dixon, M. A. (2014). Coaching fathers in conflict: A review of the tension surrounding the workfamily interface. Journal of Sport Management, 28, 447-456. DOI 10.1123/jsm.2013-0241

Ha, J. P., Hums, M. A., \& Greenwell, T. C. (2011). Dual role of physical education teacher-athletic directors in
Korean secondary schools. The Physical Educator, 68(4), 221-233. Hamner, W. C. \& Tosi, H. L. (1974). Relationship of role conflict and role ambiguity to job involvement measures. Journal of Applied Psychology, 59(4), 497-499.

Healy, T. (2015, December 10). Recruiting process starts early for elite athletes, Boston Globe. Retrieved from: https://www.bostonglobe.com/metr o/regionals/north/2015/12/10/recr uiting-process-starts-early-for-eliteathletes/V67TZxIiN54g3vraCZxr9H /story.html

Henning, J. M. \& Weidner, T. G. (2008).

Role strain in collegiate athletic training approved clinical instructors. Journal of Athletic Training, 43(3), 275283.

Hoch, D. (2008). The alarming turnover rate of athletic directors. High School Today, 1(7), 14-15.

Ivancevich, J. M. \& Donnelly, J. H., (1974). A study of role clarity and need for clarity for three occupational groups. Academy of Management Journal, 17, 2836.

Jordan, J. S., Walker, M., Kent, A. \& Inoue, Y. (2011). The frequency of nonresponse analyses in the Journal of Sport Management. Journal of Sport Management, 25, 229-239.

Kalahar, G. (2011, February 20). Job of high school athletic director evolving into multiple duties, resulting in increased burnout and turnover. Jackson Citizen 
Patriot. Retrieved from: http: www.mlive.com/sports/jackson/ind ex.ssf.2011/02/job_of_high_school_ athletic_di.html.

Kahn, R. L., Wolfe, D. M., Quinn, R. P., Snoek, J. D. \& Rosenthal, R. (1964). Organizational stress: Studies in role conflict and ambiguity. New York, NY: Wiley.

Kingwood-Oxford School (n.d.). Athletics: Sports and Schedules. Retrieved from: http://www.kingswoodoxford.org/p age.cfm? $\mathrm{p}=1122$

Larson, J. (2007). Reflections on 50 years of independent school athletics, Independent School, Retrieved from: http://www.nais.org/MagazinesNewsletters/ISMagazine/Pages/Refl ections-on-50-Years-of-IndependentSchool-Athletics.aspx

Mathis, R. \& Jackson, J. (1991).

Personnel/Human Resource Management, $\sigma^{\text {th }}$ ed. St. Paul, MN: West Publishing. Mayes, J. (2007). A private school coach living in a public school world. High School Today, 1(1).

McChesney, J. C. \& Peterson, M. (2005). There is no off-season anymore. Athletic Therapy Today, 10(6), 6-10.

McGrath, M. (2015). A big boost. Athletic Management, 27(5), 45-49.

Miss Porter's School (n.d.). Athletics: Afternoon program. Retrieved from http://www.porters.org/Page/Exper ience/Athletics/Porters-Athletics

Nagel, K. (2012). Athletic directors pull in big checks: Some high school athletic directors earn more than $\$ 100,000$.

Dayton Daily News, February 26, 2012.

National Association of Independent

Schools (2004). V alues Added: The

lifelong returns of an independent school education. Retrieved from:

http://www.aisne.org/services_resou rces/documents/NELSReport_2-304_FINAL.pdf

National Association of Independent Schools. (2015). Fast Facts. Retrieved from:

https://www.nais.org/Statistics/Doc uments/NAISFactsAtAGlance20141 5

National Association of Independent Schools (2016) Job description: Athletic Director. Retrieved from: https://www.nais.org/articles/pages /member/athletic-director.aspx

National Center for Education Statistics (1997). Public and private schools: how do they differ? Retrieved from: http://nces.ed.gov/pubs97/97983.p df

National Center for Education Statistics (2013). Fast facts. Retrieved from: http://nces.ed.gov/fastfacts/display. asp?id $=372$

National Collegiate Athletic Association. (2014). Recruiting facts. Retrieved from: https://www.ncaa.org/sites/default/ files $/$ Recruiting $\% 20$ Fact $\% 20$ Sheet $\% 2$ OWEB.pdf

National Federation of High Schools. (2015). High school athletics participation survey: A longitudinal, national study: 
1971-2015. Retrieved from

www.nfhs.org/resources/high-

school-today.

National Interscholastic Athletic

Administrators Association. (n.d.).

National Interscholastic Atbletic

Administrators Association: About.

Retrieved from:

http://www.niaaa.org/

New England Preparatory Schools Athletic

Council (n.d.). About NEPSAC:

NEPS AC Legacy. Retrieved from:

http://www.nepsac.org/page/2847

No Child Left Behind (NCLB) Act of 2001, 20 U.S.C.A. \6301 et seq. (West 2003)

Patzkowsky (2008). The successful athletic director: Planning, patience, perseverance, persistence, passion. High School Today, 1(8), 10-11.

Paul, R. J. (1974). Role clarity as a correlate of satisfaction, job related strain and propensity to leave- male vs. female. Journal of Management Studies, 11(3), 233-245.

Powell, A. G. (1996). Lessons from privilege:

The American prep school tradition.

Cambridge, MA: Harvard University Press.

Richards, K. A. \& Templin, T. J. (2012).

Toward a multidimensional perspective on teacher-coach role conflict. Quest, 64: 164-176.

DOI:10.1080/00336297.2012.693751

Richards, K. A., Templin, T. J., LevesqueBristol, C., \& Blankenship, B. T. (2014). Understanding Differences in
Role Stressors, Resilience, and Burnout in Teacher/Coaches and Non-Coaching Teachers. Journal of Teaching in Physical Education, 33, 383402.

http://dx.doi.org/10.1123/jtpe.20130159

Rizzo, J. R., House, R. J., \& Lirtzman, S. I. (1970). Role conflict and ambiguity in complex organizations, Administrative Science Quarterly, 150-163.

Robinson, M. J., Peterson, M., Tedrick, T. \& Carpenter, J. R. (2003). Job satisfaction on Division III athletic directors: Impact of job design and time on task. International Sports Journal, 46-57.

Ryan, T. D. \& Sagas, M. (2006). Interrole conflict and turnover intent in the high school teacher/coach. Journal of Sport Management, 7(4), 425-444.

Ryska (2002). Leadership styles and occupational stress among college athletic directors: The moderating effect of program goals. The Journal of Psychology, 136(2), 195-213.

Sage, G. H. (1987). The social world of high school athletic coaches: Multiple role demands and their consequences. Sociology of Sport Journal, 4, 213-228.

Schneider, R. C. \& Stier, Jr. W. F. (2001). Recommended educational experiences for high school athletic directors. Physical Educator, 58(4), 211223.

Schmidt, S., Roesler, U., Kusserow, T., \& Rau, R. (2014). Uncertainty in the 
workplace: Examining role ambiguity and role conflict, and their link to depression- a meta-analysis. European Journal of Work and Organizational Psychology, 23, 91-106.

DOI:10.1080/1359432X.2012.71152 3

Smith, P. (1992). In pursuit of happiness. In Cranny, C., Smith, P., \& Stone, E. (eds.). Job satisfaction: How People Feel About Their Jobs and How It Affects Their Performance. New York: NY; Lexington Books.

Spector, P. (1997). Job Satisfaction. Thousand Oaks, CA: Sage Publications.

Sullivan, G. S., Lonsdale, C., \& Taylor, I. (2014). Burnout in high school athletic directors: A selfdetermination perspective. Journal of Applied Sport Psychology, 26(3), 256270. DOI:10.1080/10413200.2013.853328

Terranova, A. B., \& Henning, J. M. (2011). National Collegiate Athletic Association division and primary job title of athletic trainers and their job satisfaction or intention to leave athletic training. Journal of Atbletic Training, 46(3), 312-318.

Van Milligen, D. (2013). Fund house. Atbletic Business, 37(12), 50-51.

Weight, E. A., \& Zullo, R. H. (2015). Administration of intercollegiate atbletics. Champaign, IL: Human Kinetics.

Wong, E. \& Heng, T. (2009). Case study of factors influencing job satisfaction in two Malaysian universities.
International Business Research, 2(2), 8698.

Zeveloff, J., \& Galante, M. (2011, September 6). The 31 most expensive private high schools in America, Business Insider. Retrieved from: http://www.businessinsider.com/mo st-expensive-private-high-schools-inamerica-2011-9 


\section{Appendix A}

\section{Appendix A}

The first five questions are from the "Job Satisfaction Relative to Expectations Scale" developed by Bacharach et al. (1991). Responses are obtained using a 4 point Likert-type scale where $1=$ very dissatisfied, and $4=$ very satisfied.

1. Your present job when you compare it to others in the organization.

2. The progress you are making towards the goals you have set for yourself in your present position.

3. The chance your job gives you to do what you are best at.

4. Your present job when you consider the expectations you had when you took the job.

5. Your present job in light of your career expectations.

The next eight questions are from the "Role Questionnaire" scale developed by Rizzo et al. (1970). Responses are obtained on a 7-point Likert-type scale where $1=$ strongly disagree and $7=$ strongly agree.

1. I have to do things that should be done differently.

2. I have to go against a rule of a policy in order to carry out an assignment.

3. I receive incompatible requests from two or more people.

4. I do things that are apt to be accepted by one person and not accepted by others.

5. I work on unnecessary things.

6. I work with two or more groups who operate quite differently.

7. I receive assignments without the personnel to complete them.

8. I receive assignments without adequate resources and material to execute them.

Journal of Amateur Sport Volume Three, Issue One Conant, 2017 